\title{
Axel Dreher
}

IMF and Economic Growth: The Effects of Programs, Loans, and Compliance with Conditionality

Research Paper Series

Thurgauer Wirtschaftsinstitut 


\title{
IMF and Economic Growth: The Effects of Programs, Loans, and Compliance with Conditionality
}

\author{
Axel Dreher \\ dreher@twi-kreuzlingen.ch \\ TWI and University of Konstanz
}

In theory, the IMF could influence economic growth via several channels, among them advice to policy makers, money disbursed under its programs, and its conditionality. This paper tries to disentangle those effects empirically. Using panel data for 98 countries over the period 1970-2000 it analyzes whether IMF involvement influences economic growth in program countries. Consistent with the results of previous studies, it is shown that IMF programs reduce growth rates when their endogeneity is accounted for. There is only weak evidence that compliance with conditionality mitigates this negative effect. IMF loans have no statistically significant impact.

Keywords: IMF programs, growth, compliance, conditionality

JEL: F33, F34, O57

Address: Hauptstraße 90, 8280 Kreuzlingen, Switzerland

I thank Bernhard Boockmann, Giovanni Caggiano, Martin Edwards, Ayse Evrensel, Nigar Hashimzade, Christos Kotsogiannis, Quan Li, John Maloney, Silvia Marchesi and two anonymous referees for their helpful comments and Rouben Atoian, Alexandros Mourmouras and Saleh Nsouli as well as Martin Edwards for sending me their data on program interruptions. 


\title{
1. Introduction
}

The International Monetary Fund has come under increased scrutiny and attack, with some of the most intense criticisms aiming on the link between its programs and reduced economic growth in borrower countries (e.g. Przeworski and Vreeland 2000, Hutchison 2003). The channels by which the IMF could influence growth, however, have rarely been made explicit. In no study those channels are disentangled empirically. But how could IMF programs, which are designed to stimulate economic growth, actually achieve the opposite?

In theory, the IMF can influence economic outcomes by its money, the policy conditions it attaches to its loans and, more generally, its policy advice. The overall effect of the IMF on economic growth depends on the net effect of those channels. Nevertheless, the literature so far made no attempt to disentangle them. No study did take compliance with conditionality adequately into account. ${ }^{1}$ As Joyce (2004: 12) put it:

\begin{abstract}
"This is a surprising omission, since presumably a country's economic performance will vary in response to its implementation of the program's policies. Assessing the performance of program countries without discriminating among them by their degree of compliance could give a misleading view of the effects of IMF programs. On the other hand, if no systematic linkages exist, then new questions arise about the effectiveness of Fund-supported policies and the need for conditionality."
\end{abstract}

This paper contributes to the literature in trying to disentangle the effects of programs, disbursed loans, and compliance with conditionality on economic growth. It analyzes, whether implementation of IMF conditionality influences growth rates. The paper thus

\footnotetext{
${ }^{1}$ There are, of course, several papers including the share of money disbursed under an IMF program as explanatory variables (Conway 1994, Hutchison and Noy 2003, Hajro and Joyce 2004). None of them tries to disentangle the effect of advice and money from those of compliance with conditionality and none of them uses a more direct measure of compliance. Mercer-Blackman and Unigovskaya (2004) and Nsouli, Mourmouras and Atoian (2003) employ data from the Fund's MONA database (see section 2). The former examined countries in transition to market economies between 1994 and 1997, the latter focus on a greater sample over the period
} 
combines two strands of the literature on IMF programs: those on growth and those on compliance.

What I find is, basically, that IMF programs reduce growth rates when accounting for self-selection into those programs. Depending on the proxy used for compliance, there is weak evidence that compliance with conditionality mitigates this negative effect; IMF loans do not affect economic growth.

The next section summarizes what we know about the implementation of IMF conditions, the literature on the impact of the Fund on economic growth is shortly summarized thereafter. Section 4 discusses the various channels by which the IMF could influence economic growth; section 5 describes method and data employed. Section 6 presents the empirical analysis. The final section concludes.

\section{Implementation of IMF Conditionality}

Measuring the implementation of IMF conditions is not straightforward. Many earlier studies employed proprietary data, mostly from the Fund's internal documents. Using such documents, first evidence on compliance with conditionality was presented by Beveridge and Kelly (1980). They showed that out of 105 countries with upper-credit-tranche programs implemented between 1969-78 only 60 percent achieved the target for the overall fiscal deficit and 54 percent complied with the credit ceiling. Another study on implementation of IMF conditions is Haggard (1985), who reports extremely low rates of compliance with conditions under the Extended Fund Facility (EFF) between 1974-84. Of the thirty cases studied, sixteen were cancelled and eight more were not implemented in their original form. Zulu and Nsouli (1985) found similar results in a study of African adjustment programs between 1980-81. Only half of the countries achieved the negotiated credit ceilings. Moreover, compliance with 
fiscal targets has been poor. According to Edwards (1989), conditions on the government's deficit have been achieved in only 30 percent of 34 programs approved in 1983. In 1984 compliance was reduced further: the ceiling was observed in only 19 percent of the programs. One year later, 57 percent of these countries failed to comply. As for changes in domestic credit, compliance was highest in 1983 (54.8 percent). It reduced to 46.4 percent in 1984 and 40.9 percent in 1985. On average, compliance was higher for changes in net domestic credit to the government with 72 percent in 1983 and about 52 percent in 1984 and 1985. This study has been updated by Polak (1991), who added programs in place between 1988 and 1989 . According to his results, compliance with fiscal and credit targets has been 40 percent for the 17 SAF programs and 60 percent for the five ESAF programs included in the study.

Mecagni (1999) evaluated 36 countries with an IMF program under the Structural Adjustment Facility (SAF) or the Enhanced Structural Adjustment Facility (ESAF) approved between 1986 and end-94. His findings show that 28 of the evaluated countries interrupted their programs 51 times in total. 17 countries had more than one interruption. Only 10 programs were in effect for three or four years without any major interruption and policy slippage. 38 programs made it at least one year, in the second year, 22 programs remained in effect. 33 interruptions were caused by slippage on conditionality; only eight programs broke down due to disagreements about future actions. In some cases, governments needed more time to get political support in their countries in favor of an IMF program. In 1988-89, only 40 percent of 17 countries with an SAF program complied with the postulated credit ceiling. The same is true for the overall fiscal deficit. In ten of the reviewed interruption episodes there were political upheavals. Governments were therefore not able to make credible commitments.

Edwards (2001a) analyzed 347 programs between 1979 and 1997. He gathered information from different sources, including the Fund's archives, on whether a program was suspended. His data is reproduced in Table 1, alongside other measures of interruptions that 
will be introduced below. As can be seen in column 1, interruptions have been particularly frequent between 1988-1991. Over the whole period of study, 138 programs have been suspended prior to expiration. This corresponds to a completion rate of 60 percent.

Analyzing the reasons for low completion rates, Edwards finds that international power, proxied by a country's quota with the Fund, reduced the likelihood of program suspension. Edwards (2001b) reports that the IMF is more likely to suspend programs in democratic countries having fractionalized legislatures and proportional representation systems.

Since the beginning of the Nineties the IMF itself provides data on compliance with conditionality. Its database on Monitoring Fund Arrangements (MONA) contains data on the implementation of performance criteria and structural benchmarks that have been implemented under its programs. Mercer-Blackman and Unigovskaya (2004) use these data to give evidence on compliance in countries in transition to market economies. Of the 33 countries analyzed, only 17 implemented more than 50 percent of the structural benchmarks included in their program between 1993-97. The IMF (2001) itself reports compliance with structural benchmarks in 57 percent of all programs between 1987-99. Compliance with performance criteria was almost ten percentage points higher, while prior actions have been implemented in 80 percent of the programs analyzed. The worst implementation rates were found for conditions relating to privatization (45 percent), the social security system (56 percent) and public enterprise reforms (57 percent). However, reasons for non-compliance have been evaluated only for a small subset of countries. In these countries, political and social opposition were major reasons for observed non-implementation. Ivanova, Mayer, Mourmouras and Anayiotos (2003) report that program implementation depends primarily on political constellations in the borrower country. Compliance is shown to be lower with stronger special interests, less political stability, inefficient bureaucracies, lack of political 
cohesion and greater ethno-linguistic fractionalization. Similar results are reported by Nsouli, Mourmouras and Atoian (2003). Their data is shown in column 2 of Table 1.

Unfortunately, the MONA data are not without problems (Bird and Willett 2004). Only those programs are included in the database, which have been reviewed by the Executive Board. Programs that are interrupted or permanently cancelled will therefore not be covered - which is likely to overstate compliance. As another problem with this database, coverage does not go back in time far enough to allow longer-term economic analysis.

The most widely used measure of program implementation has been a proxy suggested by Killick (1995). He employed IMF loans agreed but left undrawn at program expiration as an indicator of performance under a program. Column 3 of Table 1 contains the share of programs in effect in a certain year where more than 25 percent of the agreed money remain undrawn at program expiration.

Killick (1995) gives evidence that highly indebted countries as well as countries with small amounts of IMF credit are less likely to complete a program and that fiscal conditions are especially unlikely to be met. He also stresses that new programs are approved for political reasons even if non-compliance with conditionality of previous ones is evident. Results similar to those of Killick are reported by Mussa and Savastano (1999). Employing the same proxy, Joyce (2003) showed that a country's trade openness, its government's ideological cohesion, the duration of its political regime and its degree of political openness are significant determinants of program implementation.

Bird and Willett (2004) summarize the disadvantages of this approach. Resources may not be withdrawn, because of improvements in the economy. Sometimes programs are approved on a precautionary basis only, without intension to draw at all. On the other hand, the Fund might disburse its money even though implementation of conditions has been low, for example because it feels that significant progress has been made, or even for political reasons. There is an additional shortcoming (Dreher 2003). If countries fail to implement 
program conditions at the beginning of a multi-year arrangement, money will be withheld. In many cases this money will be paid out later, after agreement about future conditions is reached. Though non-compliance might be severe during major parts of the program period, finally the whole amount is disbursed, what would not be reflected by Killick's indicator.

In order to make up for this shortcoming, Dreher (2003) proposes a slightly revised proxy. After concluding an arrangement, part of the credit associated with it will be paid out immediately. The rest is payable in tranches. Since IMF credits are highly subsidized, countries have incentives to draw all the money available immediately. However, the money is conditional on observance of several performance criteria. Unless a waiver is granted, noncompliance results in program interruptions. If there are large unused credit lines, noncompliance is likely to be the cause. Therefore, Dreher (2003) proxied compliance using a dummy which takes the value of one if in a certain year at most 25 percent of the amount which would be available for that year under equal phasing remained undrawn and zero otherwise. Column 4 of Table 1 reports the percentage of programs interrupted according to that proxy. According to Dreher (2003) compliance depends negatively on government consumption, short-term debt and positively on GDP per capita. Compliance has also been found to be lower before national elections.

\section{IMF and Economic Growth}

Starting in the 1970s, the IMF "placed increasing emphasis on economic growth as a policy objective. Growth became increasingly prominent as an objective in the 1980 s". $^{2}$ Since then, IMF Managing Directors Michael Camdessus and Horst Köhler further highlighted the IMF's role in economic growth (Hardoy 2003).

\footnotetext{
${ }^{2}$ Cited in Hardoy (2003), http://www.imf.org/external/np/pdr/cond/2001/eng/overview/index.htm.
} 
Whether the IMF indeed influences economic growth has been subject to a huge number of studies. ${ }^{3}$ In principle, three methods of evaluation have been employed. First, before-after analysis compares economic growth before the IMF program has been approved with its value after the program period. Differences are then attributed to the program. Obviously, this method has its drawbacks. Participation in IMF programs is not exogenous but usually consequence of a crisis. In attributing all changes in growth over the program period to the IMF, the Fund's effects are probably judged too negatively.

A second approach to evaluate the IMF's impact on growth has been to compare growth rates in program countries with the development of growth in a control group (withwithout approach). Exogenous shocks hitting not only program countries but countries in the control group as well would then not distort results. The problem, of course, is finding an adequate control group. Ideally, for each program country there should be a control country in exactly the same initial position. Programs are not randomly distributed over member countries, however, but are chosen from countries with specific characteristics. As Santaella (1996) has shown, the initial situation of program countries differs greatly from non-program countries. Even if the control-group would be chosen according to economic indicators, the most important difference could not be accounted for: The decision to negotiate an IMF program in the first place. ${ }^{4}$

The third method is regression analysis - it has been used by most recent studies. When endogeneity of the IMF-related variables is carefully taken into account, this method seems to be the most promising one. However, solving the endogeneity problem is not straightforward. Most of the older studies did not even try to solve this problem, ${ }^{5}$ while more recent ones like Vreeland and Przeworski (2000) and Barro and Lee (2001) take endogeneity

\footnotetext{
${ }^{3}$ For a detailed summary of the IMF's impact on economic outcomes see Haque and Khan (1998) or Bird (2001).

${ }^{4}$ However, countries could be matched according to the probability of being under a program.
} 
into account. None of the existing studies, however, adequately separates the effects of the IMF's advice and compliance with conditionality from money disbursed. ${ }^{6}$

As can be seen in Table 2, existing studies do not provide a clear answer as to whether IMF programs affect growth and, if so, whether they increase or reduce growth rates. In part, this conflicting evidence arises from differences in country coverage, sample periods and methodology employed. However, even with similar samples and methodology, contradictory results emerge.

\section{Channels for the impact of the IMF on economic growth}

There is a multitude of channels by which the IMF can influence economic outcomes. First, program approval is obviously associated with a certain amount of money. ${ }^{7}$ The effect of this money is, however, not evident. While, in theory, IMF credit is meant to alleviate restructuring the economy, in practice the result might be the exact opposite: Money disbursed increases borrowing governments' leeway, thus reducing incentives to reform (Boockmann and Dreher 2003). As a consequence, governments pursue inappropriate policies longer than they would otherwise (Bandow 1994). ${ }^{8}$

Second, availability of IMF money may deteriorate economic policy even before it has been disbursed. According to the "moral-hazard hypothesis", IMF lending may be interpreted

\footnotetext{
${ }^{5}$ Conway (1994) is a noteworthy exception.

${ }^{6}$ Hutchison and Noy (2003) include their measures of implementation only separately but not in addition to the IMF program variable and exclude money disbursed altogether. Their measure of implementation could thus reflect the average effect of compliance with conditionality and negative incentives due to increased budgetary leeway.

${ }^{7}$ In addition to the Fund's own resources, IMF programs might exert a catalytic effect on other financial flows. Empirical support for this hypothesis is, however, rather weak. For an excellent summary of this literature see Bird and Rowlands (2002).

${ }^{8}$ According to Veiga (2002), existence of IMF arrangements in high inflation periods reduces the probability of stabilization, while the result of money disbursed is ambiguous and depends on the timing of disbursements.
} 
as a (subsidized) income insurance against adverse shocks (Vaubel 1983). ${ }^{9}$ The insurance cover induces the potential recipients to excessively lower their precautions against such damages (or even to intentionally generate a crisis). There is a considerable body of evidence that the balance of payments problems of IMF borrowers have been largely of their own making ${ }^{10}$ and that macroeconomic performance during inter-program years has been deteriorating as the number of past programs increased. ${ }^{11}$ As has been shown by Dreher and Vaubel (2004a), economic policy is indeed more expansive in countries with higher IMF loans available (as measured by the country's undrawn resources with the Fund). If it is true that the IMF induces moral hazard and thus "bad" economic policy, reduced growth would be the consequence.

Third, the Fund attaches policy conditions to its loans. Those conditions contain measures the Fund believes to be adequate to overcome crisis and stimulate growth. However, IMF conditionality has frequently been criticized as inappropriate. ${ }^{12}$ If this is true, implementation of those conditions might actually reduce growth. Moreover, it has been shown that non-compliance and program interruptions are quite frequent (see section 2). If conditions are not implemented, of course, they cannot have any (direct) impact on economic outcomes. ${ }^{13}$

\footnotetext{
${ }^{9}$ For a review of the empirical literature on moral hazard see Dreher (2004a).

${ }^{10}$ See the sources quoted in Vaubel (1991, p. 205, pp. 207) and Evrensel (2002, Table 2).

${ }^{11}$ Evrensel (2002) shows that budget deficits, inflation rates and domestic credit, among others, are higher in the second inter-program-period compared with the first. According to Conway (1994), participation in IMF programs is more likely, the more frequently the country participated in the past.

${ }^{12}$ For a summary of this literature see Bird (1986). More recent contributions are Feldstein (1998) and Meltzer (1998).

${ }^{13}$ Marchesi and Thomas (1999) develop a model where the adoption of an IMF program signals a country's productivity. Dreher (2004c) shows that conditionality can help voters in extracting the 'type' of their government. Independent of compliance with conditions, there might thus be indirect effects on economic outcomes.
} 
A fourth channel by which the IMF can influence growth is its policy advice (Boockmann and Dreher 2003). Advice of the IMF is often discussed publicly and may influence politics in the longer run (Killick 1994: 156). According to Fischer (2001: 237), one of the IMF's main contributions to reforms is that it stands consistently for a particular approach to economic policy. Therefore, the long-run impact of the IMF reaches beyond the immediate effects of conditions and finance. IMF advice to policymakers might thus stimulate (or reduce) growth independent of policy conditionality.

\section{Method and Data}

The regression is a pooled time-series cross-section analysis. Following Barro and Lee (2001), the data are averages over five years. This allows inclusion of variables that are not available on a yearly basis. The analysis covers the time period 1970-2000 and extends to 98 developing countries. ${ }^{14}$ Since some of the data are not available for all countries or periods, the panel data are unbalanced and the number of observations depends on the choice of explanatory variables.

The dependent variable is the five-year growth rate of per capita GDP. All regressions include similar covariates as Barro and Lee (2001): The log of per capita GDP at the beginning of each period, measures for human resources (secondary school enrollment, life expectancy, fertility rate), lagged values of investment and government consumption (both in percent of GDP), the rate of inflation, the growth rate of the terms of trade (all World Bank data) and an index of globalization (Dreher 2002). ${ }^{15}$ A dummy for each country and each of the five-year-periods is included in all regressions.

\footnotetext{
${ }^{14}$ Country selection is driven by data availability. The countries included in this study are listed in Appendix C.

${ }^{15}$ A previous version of the paper also included an index for the rule of law. It has been, however, insignificant in all specifications and omitting it substantially increased the number of observations. The main results are unchanged.
} 
As has been argued in section 4, the IMF might influence growth via its advice, conditionality, money, and moral hazard it induces with the borrowing governments. Only one of those channels can be directly measured: IMF loans disbursed (in percent of GDP). To proxy the degree of implementation of conditionality, ${ }^{16}$ five-year averages of three different variables introduced in section 2 are employed. First, I use the share of the agreed money actually disbursed, which has been introduced by Killick (1995) as measure of compliance with conditionality. Second, I employ the dummy proposed by Dreher (2003). It is one, if at most 25 percent of the amount which would be available for a certain year under equal phasing remained undrawn and zero otherwise. The third measure is the dummy for suspension of IMF programs established by Edwards (2001a). ${ }^{17}$ The underlying data are shown in columns 1, 3 and 4 of Table 1 . As can be seen from the Table, however, the different proxies do not provide a consistent picture. It has been outlined in section 2 that, clearly, all of them have their drawbacks, and it is therefore not obvious, which one is the most adequate measure of compliance. The results of the empirical analysis thus have to be interpreted cautiously.

In principle, the amount of IMF credit a country receives may also proxy the direct effect of advice on policies. However, advice and credit volumes are probably not proportional. The number of arrangements in effect might thus be a better measure for advice than the flows of finances (Boockmann and Dreher 2003). Controlling for the amount of credit and compliance with conditionality, the dummy for existing IMF programs would in part capture the effect of advice.

\footnotetext{
${ }^{16}$ One would also like to control for the degree of conditionality. Dreher (2004b) and Dreher and Vaubel (2004b) used the number of conditions included in the IMF program as proxy. However, those data are not available for a sufficient number of years and can therefore not be used here.

${ }^{17}$ I do not employ the data of Nsouli, Mourmouras and Atoian (2003) for the empirical analysis since they cover only nine years.
} 
Whether the IMF induces moral hazard with its borrowers can not be tested directly with those data. ${ }^{18}$ To some extent, however, the existence of an IMF program could create incentives to run "bad" economic policy in order to stay eligible for IMF money.

The analysis should cover only those arrangements that were in effect over much of the year in question. Only those years are thus coded as program years where an arrangement has been active over at least five months in a given calendar year.

Since the data are five-year averages, the participation index varies continuously between zero and one, measuring the fraction of each period, that a country operates under an IMF program. Again following Barro and Lee (2001), I only include Stand-By and Extended Fund Facility arrangements. ${ }^{19}$

When estimating the growth regressions by OLS, however, there might be a problem with endogeneity of the IMF variables..$^{20}$ Obviously, IMF programs are usually concluded in times of economic crises. The effect reported for the program variable might thus not reflect the consequences of the program itself but those of the underlying crisis. In other words, there might be a selection problem. ${ }^{21}$ The same is true for the amount of money agreed, which probably rises with the severity of crisis. Endogeneity due to self selection might even be a problem with the compliance variables. As an additional source of bias, the decision to

\footnotetext{
${ }^{18}$ In their study of fiscal and monetary policy Dreher and Vaubel (2004a) used a country's undrawn quota with the Fund to test for moral hazard. I do not use this variable here, since the effect of moral hazard on economic growth can only be an indirect one.

${ }^{19}$ Over the period of study, 512 country-years have been at least five months under an IMF Stand-By program, 157 under an EFF arrangement. Only 16 countries in the sample never participated in a program, 9 countries have been under a program for at least 15 years. Since the objectives of the Fund's concessional facilities are different from those of Stand-By and EFF arrangements, pooling them is not adequate. As an additional reason to focus on Stand-By and EFF programs, Edward's measure of suspension is only available for these unconcessional facilities.

${ }^{20}$ This is especially true since the study employs data which is averaged over five years, so low growth at the beginning of a period might cause, e.g., program participation at the end.

${ }^{21}$ Vreeland (2003) provides an extensive discussion of the selection problem in the context of IMF programs. For a detailed representation of the underlying formula, see Goldstein and Montiel (1986).
} 
participate in the IMF program might have an influence on other determinants of growth, like, e.g., policy instruments, also.

There are various methods to deal with the selection problem, and the literature on the IMF is rich on applications. Most studies pursue either some variant of Heckman's (1979) estimator or an instrumental variables approach; recently the method of matching has also been applied. ${ }^{22}$ All three of those approaches have their benefits, but also imply drawbacks. Estimating the participation equation and then including the inverse Mills ratio, as suggested by Heckman (1979), depends implicitly on auxiliary restrictions like assumptions about the distribution of error terms (Barro and Lee 2001) and the 'correct' specification of the participation equation. The challenge with the instrumental variables approach, clearly, is in finding variables that affect the probability of program participation but do not affect economic growth other than through their impact on participation. The problem of finding the correct variables is even more severe with respect to the matching approach, where matching of "treatment" and "control" groups would only result in unbiased estimates, when the decision to enter IMF programs could be accounted for by the matching procedure (see Przeworski and Limongi 1996). On theoretical grounds, thus, the choice of method is not obvious. For three reasons I chose the instrumental variables approach. First, there are good instruments available for participation in IMF programs. Second, the focus of this study is not only on IMF programs, but on loans and compliance also. Estimating the relevant equations simultaneously is thus preferable. And third, the Heckman approach is best when the selection

\footnotetext{
${ }^{22}$ With respect to the IMF and economic growth, the Heckman methodology has been employed, among others, by Przeworski and Vreeland (2000) and Hutchison (2003). However, this method usually performs poorly, with an inverse Mills ratio not significantly different from zero (Hutchison and Noy 2003, Hutchison 2004). Hardoy (2003) and Hutchison (2004) use 'matching' as their preferred choice, while Barro and Lee (2001), Easterly (2002) and Nsouli, Mourmouras and Atoian (2003) apply an instrumental variables approach. The latter approach seems to be the most popular in estimating the impact of the IMF on economic and political variables (a selection of recent papers is Marchesi 2003, Li 2003, Jensen 2004, Dreher 2004c and Dreher and Vaubel 2004b).
} 
variable is dichotomous, while the instrumental variables approach is preferable when the selection variables are continuous, which is the case for two of the three variables considered here.

As outlined above, the problem with this approach is finding reliable instruments. As possible determinants of programs, loans, and compliance, the initial regressions included a huge number of variables that have been suggested in the literature: the rate of monetary expansion, the overall budget deficit, general government consumption relative to GDP, real GDP growth, GDP per capita, the share of foreign short-term debt in total foreign debt, the total level of outstanding debt, total debt service (in percent of GDP), the rate of inflation, a country's international reserves (in months of imports), the current account balance as a percent of GDP, openness to trade (all World Bank data) and the LIBOR on three months credits to US banks (IMF 2003). I include the following political and social variables: the degree of democracy (Marshall and Jaggers 2000), a measure of political instability (Dreher 2002), ${ }^{23}$ fractionalization of the legislature, proportional representation, a dummy for special interest governments, government ideological cohesion and the duration of the political regime (all from Beck et al. 2001). All regressions also include a dummy for each individual country; where necessary an $\mathrm{AR}(1)$ term is included to correct for serial correlation. ${ }^{24}$

From the initial regressions I followed a general to specific approach, consecutively eliminating the variables with the lowest t-value. ${ }^{25}$ Eventually, only determinants significant at least at the ten percent level are retained in the regressions. Note that, potentially, many of the variables employed in the program, loans, and compliance regressions might be correlated

\footnotetext{
23 The index is constructed using principal components analysis. It employs the following categories: assassinations, strikes, guerrilla warfare, government crisis, riots and revolutions. Since those variables are highly collinear, they should not be included all separately in one regression.

${ }^{24}$ Since the variables are bounded by zero and one, I also ran Tobit regressions. The results are very similar to the within-groups regressions, so I do not report them in the tables of section 6.

${ }^{25}$ This is standard procedure. See, e.g. Sturm, Berger and de Haan (2004).
} 
with growth, so they would not be valid as instruments. I come back to this in the results section.

The next step is to replicate the OLS analysis using instruments for IMF programs, money disbursed, and compliance with conditionality. I follow Barro and Lee (2001) to account for the endogeneity of the IMF-variables and estimate 3SLS regressions. In the first stage, 3SLS uses instruments for all endogenous variables. These instruments are the predicted values resulting from a regression of each endogenous variable on all exogenous variables included in the system. The second stage estimates the covariance matrix of the equation errors using the residuals from a 2SLS estimation of each equation. In the third stage, GLS estimation employing the covariance matrix estimated in the second stage and the instruments in place of the endogenous variables is performed. This procedure is consistent and, in general, asymptotically more efficient than 2 SLS. ${ }^{26}$ Since the predicted values of the IMF variables are used instead of the actual data, 3SLS is fully adequate to account for the selection problem. The covariates that are most likely to be affected by the IMF variables, investment and government consumption, are instrumented with their own lagged values to account for potential simultaneity.

The next section reports the empirical results. After shortly summarizing the results for IMF loans, programs, and compliance with conditionality, results for the IMF's impact on economic growth are presented.

\section{Empirical Estimates}

Tables 3 and 4 report results for the IMF variables. As can be seen, only three variables have been found to be significant predictors of Fund programs. Programs are more likely the lower a country's short-term debt, the higher its debt service paid and the less democratic the country. The result for democracy is in line with other researchers claiming 
that the Fund uses its credit to support undemocratic regimes (Edwards and Santaella 1993, Bandow 1994 and Vreeland 2003). This result remains when GDP per capita and other variables controlling for development are included in the regression (not reported in the Table). A higher debt service increases demand for IMF programs and, as Dreher and Vaubel (2004a) point out, higher short-term debt probably reduces the IMF's supply. Note, however, that these results are not directly comparable to most previous studies, since the variables are averaged over five years. ${ }^{27}$

Table 3 also shows the results for IMF loans (as a percent of GDP). Loans rise significantly with higher LIBOR, lower political stability and better rule of law. They are significantly lower when the government party belongs to a special interest group. Most of those results are straightforward. LIBOR proxies interest rates in the world capital markets; with rising interest rates the interest rate subsidy provided by the Fund increases and its loans become more attractive. ${ }^{28}$ Better rule of law and lower dependence of a country's government on special interests probably increases the IMF's supply, whereas political instability is a proxy for the severity of a crisis.

Note that the explanatory variables are jointly significant at the one percent level in both regressions of Table $3 .^{29}$ However, the explained share of the dependent variable's variation is rather low.

With respect to the compliance indices (Table 4), results are somewhat disappointing. No clear pattern emerges as to what factors are important for compliance among the three

\footnotetext{
${ }^{26}$ See Zellner and Theil (1962) for a detailed treatment of 3SLS.

${ }^{27}$ For a comprehensive analysis of the determinants of IMF programs and loans employing yearly data see Sturm, Berger and de Haan (2004).

${ }^{28}$ Since 1990, however, the rates of charge have been linked to short-term market interest rates in the main industrial countries so that the subsidy is fairly constant for short-term loans.

${ }^{29}$ According to Barro and Lee (2001), a country's share of quotas and professional staff influence the size and frequency of IMF loans. I cannot employ the former in a fixed effects specification, since it varies only slightly over time; the latter is not publicly available.
} 
different measures employed. However, the explanatory variables are jointly significant at the one percent level in all three regressions. ${ }^{30}$

Program continuation is more likely with more foreign direct investment in the program country, greater freedom of the press and better rule of law. The results are easy to explain: Inflows of investment lead to (or signal) economic recovery, which makes compliance with conditionality easier, thus reducing probability of program suspension. An independent and free press is essential to provide access to information about development policy, creating support for reforms, therefore making program suspension less likely. A better rule of law also makes compliance more likely. As proxied by the index measuring equally spaced disbursement, compliance is significantly higher with a lower rate of monetary expansion, higher inflation, lower GDP per capita, higher trade volume, higher school enrollment, greater political instability and more civil liberties. Reducing monetary expansion is usually included as a performance criterion in Fund programs - high expansion thus induces the IMF to withhold its money. High inflation, low political stability and reductions in per capita GDP indicate the severity of the crisis and tend to increase compliance. The positive influence of school enrollment and civil liberties is also easy to explain: A better educated and free society better understands and participates in policy making processes, thus increasing the chance for reforms.

The share of money disbursed relative to money agreed over the five-year-period is significantly higher in more democratic countries and when inflation is low. Democratic governments frequently include conditions in IMF programs which serve their own interests (Vreeland 1999). This is because they can then blame the IMF for their policies ("scapegoat hypothesis"). Compliance is thus more likely. High inflation, to the contrary, makes compliance more difficult.

\footnotetext{
${ }^{30}$ Note that in the compliance-regressions only those countries and periods were included where an IMF program has been in effect.
} 
Table 5 reports the growth regressions without employing instruments. As can be seen, most explanatory variables have the expected sign. Growth rates significantly rise with lower initial GDP, lower fertility rates, longer life expectancy and lower inflation. Globalization and an improvement in the terms of trade significantly promote growth. Secondary school enrollment and (lagged) government consumption do not significantly influence economic growth, while (lagged) investment enters insignificantly at the five percent level always, but significantly at the ten percent level in some specifications and, surprisingly, with a negative coefficient.

With respect to the influence of the IMF, results are rather disappointing. IMF programs and new IMF loans (in percent of GDP) are never significant at conventional levels. The share of agreed IMF loans actually disbursed over the program period reduces growth at the one percent level of significance (column 3a). If interacted with the program participation variable, however, the effect becomes insignificant (column 4a). ${ }^{31}$ Compliance as measured with Edward's index also reduces growth at the one percent level of significance if included separately in the regression (column $3 b$ ) and has no effect when interacted with program participation (column 4b). If measured by equally phased disbursements, compliance seems to reduce growth further in the full model of column $4 \mathrm{c}$ (and has no effect according to the estimates in column 3c).

The negative impact of compliance may be due to the endogeneity of compliance: The more severe the crisis, the more likely it is the government breaches the Fund's conditionality, giving rise to the significantly negative coefficient. As an alternative explanation, of course, IMF conditions might be harmful to growth, so that compliance with those conditions worsens performance. This is particularly likely in the short run where a devaluation of the

\footnotetext{
${ }^{31}$ The compliance measures do not enter specifications $4 a-4 c$ individually, since compliance is highly correlated with program participation. Clearly, compliance can only be observed, when programs are in effect.
} 
domestic currency and tight fiscal and monetary policy have for a long time been the preferred measures to deal with balance-of-payments crises. ${ }^{32}$

Table 6 presents results when IMF programs, loans, and compliance with conditionality are instrumented. In the first stage of the regressions, the endogenous variables are thus regressed on all exogenous variables included in the system. However, only those variables can be used as instruments that do not have a direct impact on economic growth. Inflation and school enrollment are included in the growth regressions also, and can thus not serve as instruments. ${ }^{33}$ IMF programs are instrumented with short-term debt, total debt service, and the index of democracy; IMF loans with LIBOR, political instability and the dummy for special interest governments; the index for no program suspension with foreign direct investment and the freedom of the press index; equally phased loan disbursements with monetary expansion, GDP per capita, trade, political instability and civil liberties; and the share of agreed IMF loans drawn with the index of democracy. Note that the instrumental variables are jointly insignificant when included in the growth regressions directly.

Instruments for the covariates are the actual values of the variables for school enrollment, inflation, life expectancy, globalization, fertility and the growth rate of the terms of trade; lagged values of investment and government consumption; and the initial value of each period of per capita GDP. As can be seen, IMF money is again insignificant in all regressions, giving no support to the hypothesis that the Fund's loans lead to worse economic policy by increasing governments budgetary leeway. ${ }^{34}$

In all regressions, program participation significantly reduces growth. Compliance increases growth in the full model of column $4 \mathrm{~b}$ when measured by Edward's index, but only

\footnotetext{
${ }^{32}$ See also Stiglitz (2000).

${ }^{33}$ The coefficient of school enrollment enters the growth regressions always insignificantly. Since the regressors have been chosen according to theroretical considerations, I nevertheless keep the variable in the regressions.

${ }^{34}$ Contrary to this, Boockmann and Dreher (2003) found some evidence that IMF loans make growth-oriented policies in the borrower countries less likely.
} 
at the ten percent level of significance. The negative influence of the compliance measure for equally phased disbursements reported in the previous Table disappears when instruments for compliance are employed (column 4c). It thus seems that the main reason for the significantly negative coefficient reported in Table 5 is the endogeneity of compliance with conditionality.

According to the estimates of column $4 \mathrm{~b}$, economic growth is on average 7.48 percentage points lower when an IMF program has been in effect over the whole five-yearperiod, which amounts to about 1.5 percentage points per year. This is in line with results of previous studies, estimating the costs of IMF programs in terms of foregone output to be in the range of 0.7-2.5 percentage points during each year of program participation (Hutchison 2004). If there has been full compliance over this period, the negative effect is reduced by 0.06 percentage points (or slightly more than 0.01 percentage points per year).

In summary, there is considerable evidence that participation in IMF programs reduces economic growth when endogeneity is taken into account. Depending on the proxy employed, there is some evidence that compliance with conditionality reduces this negative effect.

The negative impact of IMF programs holding compliance and loans disbursed constant is not easy to explain. There are some possibilities. As argued above, this variable might measure the IMF's advice (in excess of conditionality). The negative result would thus lead to the conclusion that the IMF's concept of economic reforms is flawed and in the long run, even when conditionality is not implemented, reduces growth. To some extent this negative impact might also reflect the effects of moral hazard. If the intention to sign an IMF program deteriorates economic policy, this would increase the probability of actual program approvals and, at the same time, would decrease economic growth. Similarly, in order to stay eligible for IMF money, necessary changes might be delayed. The existence of an IMF program could thus produce incentives to run "bad" economic policy and would so lower growth. 
Alternatively, the instruments employed might not adequately capture the underlying crises, so that the effect of the IMF is outweighed by the effect of the crises. And finally, the proxies for compliance might be too crude to actually capture true implementation of conditionality.

\section{Summary and Conclusion}

"Our primary objective is growth" (Michael Camdessus, former IMF Managing Director, Statement before the United Nations Economic and Social Council in Geneva, July 11, 1990, cited in Przeworski and Vreeland 2000).

As has been shown in several studies, with respect to this objective, IMF programs are a failure. This paper provided further evidence. While supporting previous results on the negative relationship between IMF programs and economic growth, there is some, albeit weak, evidence that compliance with IMF conditionality does increase growth rates once taking account of sample selection. In any case, the effect of compliance is quantitatively small compared to the overall reduction and depends on the proxy employed for compliance. Since IMF loans and compliance are controlled for in the empirical analysis, the remaining negative impact of IMF programs might probably either be due to "bad" advice given by the IMF or the moral hazard it induces with its borrowers. To further disentangle the components reflected by the program participation variable remains an interesting area for future research.

The results have implications for the design of conditionality. Whether or not the IMF should impose conditions on sovereign countries has been highly debated from the very beginning of the IMF's operations. ${ }^{35}$ It has recently been shown that its conditions do not influence economic policy (Dreher and Vaubel 2004b). The empirical results of this paper have shown that if compliance with conditionality has an impact on growth at all, this impact is quantitatively small. As one interpretation of this result, conditions imposed by outside 
actors might be circumvented, even if the officially agreed criteria have been met. To some extent, the results of this paper support Dollar and Svensson (2000), who show that governments which are inclined to reform must be identified and can not be created by international organizations. In order to lend more effectively, it would therefore be most important for the IMF to detect factors influencing ownership and thus the willingness to reform. Arguably, if the IMF would support reform-minded governments, its loans might make a difference (even if its advice might not).

The results also allow a different interpretation. As claimed by the IMF, conditions are the outcome of a bargaining process between government and Fund. ${ }^{36}$ They might therefore reflect the government's agenda instead of being imposed by the IMF. As a consequence, compliance with conditionality does not make a difference with respect to economic growth the same policies would have been implemented without the Fund's conditions. In any case conditionality would not be necessary.

\footnotetext{
${ }^{35}$ For a recent discussion of the theoretical arguments see Dreher and Vaubel (2004b).

${ }^{36}$ Conwy (2003) provides empirical evidence in support of this claim.
} 


\section{References}

Bagci, P. and W. Perraudin, 1997, The Impact of IMF Programmes, The Institute For Financial Research Working Paper 35, Birkbeck College: University of London.

Bandow, Doug, 1994, The IMF: A Record of Addiction and Failure, in: Doug Bandow and Ian Vásquez (eds.), Perpetuating Poverty; The World Bank, the IMF, and the Developing World. Washington, D.C.: Cato Institute, 15-36.

Barro, Robert J. and Jong-Wha Lee, 2001, IMF-Programs: Who Is Chosen and What are the Effects? Paper presented at the IMF Annual Research Conference November 29-30.

Beck, Thorsten, Clarke, George, Groff, Alberto, Keefer, Philip and Patrick Walsh, 2001, New tools in comparative political economy: The Database of Political Institutions, World Bank Economic Review 15: 1, 165-176.

Beveridge, W.A. and M.R. Kelly, 1980, Fiscal Content of Financial Programs Supported by Stand-By Arrangements in the Upper Credit Tranches, 1969-78, IMF Staff Papers 27, 205-249.

Bird, Graham, 1986, Relationships, Resource Uses and the Conditionality Debate, in: Tony Killick (ed.), The Quest for Economic Stabilisation, The IMF and the Third World, Aldershot, 145-182.

Bird, Graham, 2001, IMF Programs: Do They Work? Can They Be Made To Work Better? World Development 29, 11, 1849-1865.

Bird, Graham and Dane Rowlands, 2002, Do IMF Programmes have a Catalytic Effect on other International Capital Flows? Oxford Development Studies 20, 3, 229-249.

Bird, Graham and Thomas Willett, 2004, IMF Conditionality, Implementation and the New Political Economy of Ownership, mimeo.

Boockmann, Bernhard and Axel Dreher, 2003, The Contribution of the IMF and the World Bank to Economic Freedom, European Journal of Political Economy 19, 3, 633-649.

Bordo, Michael and Anna J. Schwartz, 2000, Measuring Real Economic Effects of Bailouts: Historical Perspectives on How Countries in Financial Distress Fared With and Without Bailouts, NBER working paper 7709.

Butkiewicz, James L. and Yanikkaya, Halit, 2003, An Assessment of the Effectiveness of International Financial Intervention, Working Paper No. 2003-05, Alfred Lerner College of Business \& Economics, University of Delaware.

Connors, Thomas A., 1979, The Apparent Effects of Recent IMF Stabilization Programs, International Finance Discussion Papers 135, Board of Governors of the Federal Reserve System. 
Conway, Patrick, 1994, IMF lending programs: Participation and impact, Journal of Development Economics 45, 365-391.

Conway, Patrick, 2003, Endogenous IMF Conditionality: Theoretical and Empirical Implications, mimeo, University of North Carolina Chapel Hill.

Dicks-Mireaux, Louis, Mecagni, Mauro and Susan Schadler, 2000, Evaluating the effect of IMF lending to low-income countries, Journal of Development Economics 62, 495526.

Dollar, David and Jakob Svensson, 2000, What Explains the Success or Failure of Structural Adjustment Programs? Economic Journal 110, 466: 894-917.

Donovan, Donal J., 1981, Real Responses Associated with Exchange Rate Action in Selected Upper Credit Tranche Stabilization Programs, IMF Staff Papers 28, 698-727.

Donovan, Donal J., 1982, Macroeconomic Performance Under Fund-Supported Programs: The Experience of the Seventies, IMF Staff Papers 29, 171-203.

Doroodian, K., 1993, Macroeconomic Performance and Adjustment under Policies Commonly Supported by the International Monetary Fund, Economic Development and Cultural Change 41, 4, 849-864.

Dreher, Axel, 2002, Does Globalization Affect Growth? mimeo, University of Mannheim.

Dreher, Axel, 2003, The Influence of Elections on IMF Program Interruptions, The Journal of Development Studies 39,6, 101-120.

Dreher, Axel, 2004a, Does the IMF cause moral hazard? A critical review of the evidence, mimeo, Exeter University.

Dreher, Axel, 2004b, A Public Choice Perspective of IMF and World Bank Lending and Conditionality, Public Choice 119, 3-4: 445-464.

Dreher, Axel, 2004c, The Influence of IMF Programs on the Re-election of Debtor Governments, Economics \& Politics 16, 1, 53-76.

Dreher, Axel and Roland Vaubel, 2004a, Do IMF and IBRD cause moral hazard and political business cycles? Evidence from panel data, Open Economies Review 15, 1, 5-22.

Dreher, Axel and Roland Vaubel, 2004b, The Causes and Consequences of IMF Conditionality, Emerging Markets Finance and Trade 40, 3, 26-54.

Easterly, William, 2002, What did Structural Adjustment Adjust? The Association of Policies and Growth with Repeated IMF and World Bank Adjustment Loans, Journal of Development Economics, forthcoming.

Edwards, Martin S., 2001a, Crime and Punishment: Understanding IMF Sanctioning Practices, mimeo, Rutgers University. 
Edwards, Martin S., 2001b, Sticking with Yes: Domestic Institutions and IMF Compliance, mimeo, Rutgers University.

Edwards, Sebastian, 1989, The International Monetary Fund and the Developing Countries: A Critical Evaluation, Carnegie-Rochester Conference Series on Public Policy: IMF Policy Advice, Market Volatility, Commodity Price Rules and other Essays, NorthHolland, 7-68.

Edwards, Sebastian and Julio Santaella, 1993, Devaluation Controversies in the Developing Countries: Lessons from the Bretton Woods Era, in: Michael Bordo and Barry Eichengreen (eds.), A Retrospective on the Bretton Woods System. The University of Chicago Press, 405-455.

Evrensel, Ayse, 2002, Effectiveness of IMF-Supported Stabilization Programs in Developing Countries, Journal of International Money and Finance 21, 5, 565-587.

Faini, Riccardo, de Melo, Jaime, Senhadji-Semlali, Abdel and Julie Stanton, 1991, Macro Performance under Adjustment Lending, in Vinod Thomas, Ajay Chibber, Mansoor Dailami and Jaime de Melo (eds.), Restructuring Economies in Distress, Oxford University Press.

Feldstein, Martin, 1998, Refocusing the IMF, Foreign Affairs, March/ April Issue.

Fischer, Stanley, 2001, Address in Moscow, IMF Survey 30, 14, July 16, 2001, 237-239.

Goldstein, Morris and Peter Montiel, 1986, Evaluating Fund Stabilization Programs with Multicountry Data, IMF Staff Papers 33, 304-344.

Gylfason, Thorvaldur, 1987, Credit Policy and Economic Activity in Developing Countries with IMF Stabilization Programs, International Finance Section, Princeton Studies in International Finance 60.

Gwartney, James and Robert Lawson, 2002, Economic Freedom of the World: Annual Report, http://www.freetheworld.org/.

Haggard, Stephan, 1985, The Politics of Adjustment: Lessons from the IMF's Extended Fund Facility, International Organization 39, 3, 505-534.

Hajro, Zlata and Joyce, Joseph P., 2004, A True Test: Do IMF Programs Hurt the Poor?, Wellesley College Department of Economics Working Paper \#04-01.

Haque, Naadem Ul and Moshin S. Khan, 1998, Do IMF-Supported Programs Work? A Survey of the Cross-Country Empirical Evidence, IMF Working Paper 98/169.

Hardoy, Ines, 2003, Effect of IMF Programmes on Growth: A Reappraisal Using the Method of Matching, Paper presented at the European Economic Association, Stockholm, 20.24. August 2003. 
Heckman, J., 1979, Sample Selection Bias as a Specification Error, Econometrica 47, 1, 153 161.

Hutchison, Michael M., 2003, A Cure Worse than the Disease? Currency Crises and the Output Costs of IMF-Supported Stabilisation Programs, in: Michael Dooley and Jeffrey A. Frankel (eds.), Managing Currency Crises in Emerging Markets, Chicago, chapter 10 .

Hutchison, Michael M. and Illan Noy, 2003, Macroeconomic Effects of IMF-sponsored Programs in Latin America: Output Costs, Program Recidivism and the Vicious Cycle of Failed Stabilization, Journal of International Money and Finance 22, 7, 991-1014.

Hutchison, Michael M., 2004, Selection Bias and the Output Costs of IMF Programs, mimeo, University of California, Santa Cruz.

International Monetary Fund, 2001, Structural Conditionality in Fund-Supported Programs, February 16, http://www.imf.org.

International Monetary Fund, 2003, International Financial Statistics Indicators, CD-ROM, Washington, D.C.

Ivanova, Anna, Mayer, Wolfgang, Mourmouras, Alex and George Anayiotos, 2003, What Determines the Implementation of IMF-Supported Programs? IMF Working Paper $03 / 8$.

Jensen, Nathan, 2004, Crisis, Conditions, and Capital: The Effects of International Monetary Fund Agreements on Foreign Direct Investment Inflows, Journal of Conflict Resolution 48, 2, 194-210.

Joyce, Joseph P., 2003, Promises Made, Promises Broken: A Model of IMF Program Implementation, Wellesley College Department of Economics Working Paper 200303.

Joyce, Joseph P., 2004, The Adoption, Implementation and Impact of IMF Programs: A Review of the Issues and Evidence, Comparative Economics Studies, forthcoming.

Khan, Mohsin S., 1990, The Macroeconomic Effects of Fund-Supported Adjustment Programs, IMF Staff Papers 37, 195-231.

Killick, Tony, 1986, The Impact of Fund Stabilisation Programmes, in: Tony Killick (ed.), The Quest for Economic Stabilization: The IMF and the Third World, St. Martin's, New York, 227-269.

Killick, Tony, 1994, Adjustment and Economic Growth, in: J.M. Boughton and K.S. Lateef (eds.), Fifty Years after Bretton Woods - The Future of the IMF and the World Bank, International Monetary Fund and World Bank Group, Washington, D.C. 
Killick, Tony, 1995, IMF Programmes in Developing Countries - Design and Impact, Routledge, London.

Killick, Tony, Malik, Moazzam and Marcus Manuel, 1992, What can we know about the effects of IMF programmes? The World Economy 15, 5, 575-597.

Li, Quan, 2003, IMF Programs and Financial Liberalization in the Developing World, Prepared for presentation at the Annual Meeting of the Midwest Political Science Association, Chicago, IL, April 4, 2003.

Loxley, John, 1984, The IMF and the Poorest Countries: The Performance of the Least Developed Countries Under IMF Stand-By Arrangements, The North-South Institute, Ottawa.

Marchesi, Silvia and Jonathan P. Thomas, 1999, IMF Conditionality as a Screening Device, Economic Journal 109: C111-C125

Marchesi, Silvia, 2003, Adoption of an IMF Programme and Debt Rescheduling. An empirical analysis, Journal of Development Economics 70, 2, 403-423.

Marshall, M.G. and K. Jaggers, 2000, Polity IV project: political regime characteristics and transitions, 1800-2000, http://www.cidcm.umd.edu/inscr/ polity/.

Meltzer, Allan H., 1998, What's Wrong with the IMF? What would be better? AEI Speeches, October 8-10.

Mecagni, Mauro, 1999, The Causes of Program Interruptions, in: H. Bredenkamp and S. Schadler (eds.), Economic Adjustment in Low-Income Countries, International Monetary Fund, Washington, D.C., 215-276.

Mercer-Blackman, Valerie and Anna Unigovskaya, 2004, Compliance with IMF Program Indicators and Growth in Transition Economies, Emerging Markets Finance and Trade 40, 3: 55-83.

Mussa, Michael and Miguel Savastano, 1999, The IMF Approach to Economic Stabilisation, IMF Working Paper, Washington, D.C.

Nsouli, Saleh, Mourmouras, Alex and Rouben Atoian, 2003, IMF Program Implementation, Institutional and Political Environment, and Macroeconomic Outcomes, mimeo.

Pastor, Manuel JR., 1987, The Effects of IMF Programs in the Third World: Debate and Evidence from Latin America, World Development 15, 2, 249-262.

Polak, Jacques J., 1991, The Changing Nature of IMF Conditionality. Essay in International Finance No. 184. Princeton, NJ: Princeton University.

Przeworski, A. and F. Limongi, 1996, Selection, counterfactuals and comparison, mimeo, University of Chicago. 
Przeworski, A. and James R. Vreeland, 2000, The Effect of IMF Programs on Economic Growth, Journal of Development Economics 62, 385-421.

Reichmann, T.M. and T. Stillson, 1987, Experience with Programs of Balance of Payments Adjustment in the Higher Tranches, 1963-72, IMF Staff Papers 25, 293-309.

Santaella, J.A., 1996, Stylized Facts Before IMF-Supported Macroeconomic Adjustment, IMF Staff Papers. 43, 3, 502-544.

Schadler, Susan, Rozwadowski, Franek, Tiwari, Siddharth and David O. Robinson, 1993, Economic Adjustment in Low-Income Countries: Experience Under the Enhanced Structural Adustment Facility, IMF Occasional Paper 106.

Stiglitz, Jospeh, 2000, Globalization and the Logic of International Collective Action: Reexamining the Bretton Woods Institutions, in: D. Nayyar (ed.), Governing Globalization: Issues and Institutions, Oxford University Press.

Sturm, Jan-Egbert, Berger, Helge and Jakob de Haan, 2004, Which Variables Explain Decisions on IMF Credit? An Extreme Bounds Analysis, mimeo.

Vaubel, Roland, 1983, The Moral Hazard of IMF Lending, in: Allan H. Meltzer (ed.), International Lending and the International Monetary Fund: A Conference in Memory of Wilson E. Schmidt. Washington, D.C.: Heritage Foundation, 65-79.

Vaubel, Roland, 1991, The Political Economy of the International Monetary Fund: A Public Choice Approach, in: Roland Vaubel and Thomas D. Willett (eds.), The Political Economy of International Organisations, Boulder, Westview, 205-245.

Veiga, Francisco J., 2002, IMF Arrangements, Politics and the Timing of Stabilizations, Universidade do Minho, NIPE Working Paper No. 2/2002.

Vreeland, James R., 1999, The IMF: Lender of Last Resort or Scapegoat?, mimeo.

Vreeland, James R., 2003, The IMF and Economic Development. Cambridge: Cambridge University Press.

World Bank (2002), Global Development Finance, CD-ROM, Washington, D.C.

World Bank (2003), World Development Indicators, CD-ROM, Washington, D.C.

Zellner, Arnold and Henri Theil, 1962, Three-Stage Least Squares: Simultaneous Estimation of Simultaneous Equations, Econometrica 30, 54-78.

Zulu, Justin B. and Saleh M. Nsouli, 1985, Adjustment Programs in Africa: The Recent Experience, IMF Occasional Papers 34, Washington, D.C. 
Table 1: Interruptions of IMF Stand-By and EFF Programs

(1)

(2)

1970

1971

1972

1973

1974

1975

1976

1977

1978

$1979 \quad 18$

$1980 \quad 33$

$1981 \quad 40$

$1982 \quad 31$

$1983 \quad 36$

$1984 \quad 39$

$1985 \quad 39$

$1986 \quad 43$

$1987 \quad 37$

$1988 \quad 49$

$1989 \quad 48$

$1990 \quad 56$

$1991 \quad 45$

$1992 \quad 39$

$1993 \quad 29$

$1994 \quad 22$

$1995 \quad 21$

199633

1997

1998

1999

67

67

2000
(3)

57

65

$58 \quad 37$

$54 \quad 61$

$70 \quad 47$

$44 \quad 35$

$58 \quad 63$

$64 \quad 53$

$56 \quad 46$

$69 \quad 52$

$52 \quad 71$

$56 \quad 68$

$62 \quad 68$

$21 \quad 65$

$39 \quad 57$

$48 \quad 49$

$42 \quad 55$

$30 \quad 73$

$48 \quad 67$

$19 \quad 64$

$58 \quad 80$

$78 \quad 62$

$59 \quad 63$

$48 \quad 58$

$29 \quad 71$

$38 \quad 72$

$22 \quad 72$

$39 \quad 77$

$29 \quad 69$

$\begin{array}{lll}40 & 30 & 57 \\ 57 & 57 & 61\end{array}$

$40 \quad 60$

(1): Percentage of countries that were not eligible for all of the drawings either because they missed performance criteria and were unable to obtain a waiver from the Fund or they failed a quarterly review (Source: Edwards 2001a).

(2): Percentage of programs approved, which were irreversibly interrupted during the intended period (Source: Nsouli, Mourmouras, Atoian 2003).

(3): Percentage of programs in effect in a certain year where more than 25 percent of the agreed money remain undrawn at program expiration (Source: own calculations).

(4): Percentage of programs where at least 25 percent of the amount which would be available for that year under equal phasing remained undrawn (Source: Dreher 2003). 
Table 2: IMF and Economic Growth

\begin{tabular}{|c|c|c|c|c|}
\hline Study & Period & \begin{tabular}{|l|}
$\begin{array}{l}\text { Number of } \\
\text { Programs }\end{array}$ \\
\end{tabular} & $\begin{array}{l}\text { Number of } \\
\text { Countries }\end{array}$ & \begin{tabular}{|l|} 
Effect on \\
Growth
\end{tabular} \\
\hline \multicolumn{5}{|l|}{ Before-After } \\
\hline Reichman and Stillson (1978) & $1963-72$ & 79 & n.a. & Increase \\
\hline Connors (1979) & $1973-77$ & 31 & 23 & None \\
\hline Zulu and Nsouli (1985) & $1980-81$ & 35 & 22 & None \\
\hline Killick (1986) & $1974-79$ & 38 & 24 & None \\
\hline Pastor (1987) & $1965-81$ & n.a. & 18 & None \\
\hline Killik, Malik and Manuel (1992) & $1979-85$ & n.a. & 16 & Increase \\
\hline Schadler et al. (1993) & $1983-93$ & 55 & 19 & Increase \\
\hline Evrensel (2002) & $1971-97$ & n.a. & 109 & None \\
\hline Hardoy (2003) & $1970-90$ & 460 & 69 & None \\
\hline \multicolumn{5}{|l|}{ With-without } \\
\hline Donovan (1981) & $1970-76$ & 12 & 12 & Increase \\
\hline Donovan (1982) & 1971-80 & 78 & 44 & Decrease \\
\hline Loxley (1984) & $1971-82$ & 38 & 38 & None \\
\hline Gylfason (1987) & $1977-79$ & 32 & 14 & None \\
\hline Faini et al. (1991) & $1978-86$ & n.a. & 93 & None \\
\hline Hardoy (2003) & $1970-90$ & 460 & 69 & None \\
\hline Hutchison (2004) & $1975-97$ & 455 & 25 & None \\
\hline \multicolumn{5}{|l|}{ Regression-based } \\
\hline Goldstein and Montiel (1986) & $1974-81$ & 68 & 58 & None \\
\hline Khan (1990) & $1973-88$ & 259 & 69 & Decrease \\
\hline Doroodian (1993) & $1977-83$ & 27 & 43 & None \\
\hline Conway (1994) & $1976-86$ & 217 & 73 & Increase \\
\hline Bagci and Perraudin (1997) & 1973-92 & n.a. & 68 & Increase \\
\hline Bordo and Schwarz (2000) & $1973-98$ & n.a. & 24 & Decrease \\
\hline Dicks-Mireaux et al. (2000) & $1986-91$ & 88 & 74 & Increase \\
\hline Przeworski and Vreeland (2000) & $1970-90$ & 465 & 135 & Decrease \\
\hline Barro and Lee (2001) & $1975-99$ & 725 & 81 & Decrease \\
\hline Easterly $(2002)^{*}$ & $1980-99$ & 107 & 107 & None \\
\hline Butkiewicz andYanikkaya (2003) & $1970-99$ & 407 & n.a. & Decrease \\
\hline Hutchison (2003) & $1975-97$ & 461 & 67 & Decrease \\
\hline Hutchison and Noy (2003) & $1975-97$ & 764 & 67 & Decrease \\
\hline Nsouli, Mourmouras, Atoian (2003) & $1992-2000$ & 124 & 92 & None \\
\hline
\end{tabular}

* This study focuses on IMF and World Bank programs. 
Table 3: Determinants of IMF programs and loans (98 countries, 1970-2000, OLS)

\section{IMF programs in effect}

IMF loans (in percent of GDP)

Short-term debt (percent of total debt)

$-0.01$

LIBOR

1.60

$\left(2.78^{*}\right)$

Total debt service (in percent of GDP)

$0.01 \quad$ Political instability

26.10

$\left(2.00^{* *}\right)$

$(4.42 *)$

Democracy, index

$-0.02$

Government special

$-17.44$

$\left(2.43^{* *}\right)$

interest

$\left(1.82^{\circ}\right)$

Rule of law, index

\begin{tabular}{lcc}
\hline Number of observations & 351 & 299 \\
$\mathrm{R}_{-}$ & 0.07 & 0.13 \\
Joint significance (Prob $>\mathrm{F})$ & 0.000 & 0.000 \\
\hline
\end{tabular}

Notes:

'IMF programs' is the five-year average of yearly dummies that take the value of one if there has been an IMF Stand-By or Extended Fund Facility arrangement in a certain year for at least five months. 'IMF loans' is the five-year average of disbursed loans in percent of GDP.

t-statistics in parentheses.

Levels of significance: 1 percent $(*), 5$ percent $(* *), 10$ percent $\left({ }^{\circ}\right)$.

The regressions include dummies for each country. 
Table 4: Compliance with IMF conditionality (98 countries, 1970-2000, OLS)

\begin{tabular}{|c|c|c|}
\hline m suspension & $\begin{array}{c}\text { Equally phased loan } \\
\text { disbursement }\end{array}$ & $\begin{array}{c}\text { Share of agreed IMF } \\
\text { loans drawn }\end{array}$ \\
\hline
\end{tabular}
$\begin{array}{llllll}\text { Foreign direct investment } & 0.08 & \text { Monetary expansion } & -0.0004 & \text { Inflation } & -0.0003\end{array}$

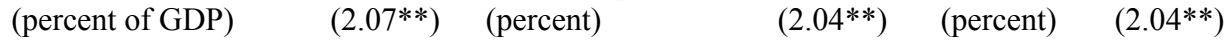
$\begin{array}{lllll}\text { Freedom of the press, } \quad 0.01 \text { Inflation } & 0.0002 \text { Democracy, } & 0.04\end{array}$ index
Rule of law, index
$\left(2.52^{* *}\right) \quad$ (percent)
$\left(2.52^{* *}\right)$ index
$(3.42 *)$
$\left(1.98^{* *}\right)$
$-0.02$
$\left(1.72^{\circ}\right)$
Trade (percent of
0.27
GDP)
School enrollment
$(2.42 * *)$
0.02
$\left(1.88^{\circ}\right)$
Political instability,
0.33
index
$\left(1.89^{\circ}\right)$
Civil liberties, index
0.13
$\left(2.39^{* *}\right)$

\begin{tabular}{lccc}
\hline Number of observations & 114 & 107 & 215 \\
$\mathrm{R}$ & 0.21 & 0.49 & 0.10 \\
Joint significance & 0.006 & 0.000 & 0.001 \\
(Prob>F) & & & \\
\hline
\end{tabular}

Notes:

'No program suspension' is the share of a five-year period where (according to Edwards 2001a) no program suspension occurred. 'Equally phased loan disbursement' is the five-year average of a dummy that is one when in a certain year at most 25 percent of the amount which would be available for that year under equal phasing remained undrawn and zero otherwise. 'Share of agreed IMF loans drawn' is the share of money agreed under an IMF program actually drawn until program expiration.

$\mathrm{t}$-statistics in parentheses.

Levels of significance: 1 percent $(*), 5$ percent $(* *), 10$ percent $\left({ }^{\circ}\right)$.

The regressions include dummies for each country. 
Table 5: Effects of the IMF on Economic Growth (98 countries, 1970-2000, OLS)

\begin{tabular}{|c|c|c|c|c|c|c|c|c|}
\hline & 1 & 2 & $3 a$ & $3 \mathrm{~b}$ & $3 \mathrm{c}$ & $4 a$ & $4 \mathrm{~b}$ & $4 \mathrm{c}$ \\
\hline MF Program & $\begin{array}{l}-0.34 \\
(0.71)\end{array}$ & & & & & $\begin{array}{c}0.37 \\
(0.50)\end{array}$ & $\begin{array}{l}-0.29 \\
(0.43)\end{array}$ & $\begin{array}{l}-0.03 \\
(0.06)\end{array}$ \\
\hline MF Loans & & $\begin{array}{l}0.001 \\
(0.26)\end{array}$ & & & & $\begin{array}{l}0.003 \\
(0.58)\end{array}$ & $\begin{array}{l}0.002 \\
(0.45)\end{array}$ & $\begin{array}{l}0.002 \\
(0.40)\end{array}$ \\
\hline omp & & & $\begin{array}{c}-1.36 \\
\left(3.75^{*}\right)\end{array}$ & $\begin{array}{c}-0.93 \\
\left(2.70^{*}\right)\end{array}$ & $\begin{array}{l}-0.68 \\
(1.36)\end{array}$ & & & \\
\hline MF Prog & & & & & & $\begin{array}{l}-1.29 \\
(1.40)\end{array}$ & $\begin{array}{l}-0.18 \\
(0.22)\end{array}$ & $\begin{array}{c}-3.11 \\
\left(2.48^{* *}\right)\end{array}$ \\
\hline $\begin{array}{r}\text { og (per } \\
\text { begin }\end{array}$ & & $\begin{array}{l}-11.03 \\
(5.87 *)\end{array}$ & $\begin{array}{l}-10.28 \\
\left(5.97^{*}\right)\end{array}$ & $\begin{array}{l}-10.89 \\
\left(6.05^{*}\right)\end{array}$ & & $\begin{array}{l}-11.08 \\
\left(5.89^{*}\right)\end{array}$ & $\begin{array}{l}-11.24 \\
\left(5.88^{*}\right)\end{array}$ & $\begin{array}{l}-11.11 \\
(5.94 *)\end{array}$ \\
\hline $\begin{array}{r}\text { econda } \\
\text { Enrol }\end{array}$ & $\begin{array}{l}-0.02 \\
(0.62)\end{array}$ & $\begin{array}{l}-0.02 \\
(0.90)\end{array}$ & & & & $\begin{array}{l}-0.02 \\
(0.71)\end{array}$ & $\begin{array}{l}-0.02 \\
(0.84)\end{array}$ & $\begin{array}{l}-0.01 \\
(0.52)\end{array}$ \\
\hline $\operatorname{og}$ & $\begin{array}{c}5.82 \\
(2.07 * *)\end{array}$ & $\begin{array}{c}5.72 \\
(2.02 * *)\end{array}$ & $\begin{array}{c}6.64 \\
(2.41 * *)\end{array}$ & $\begin{array}{c}5.96 \\
\left(2.15^{* *}\right)\end{array}$ & $\begin{array}{c}5.90 \\
(2.11 * *)\end{array}$ & $\begin{array}{c}6.34 \\
(2.22 * *)\end{array}$ & $\begin{array}{c}5.99 \\
\left(2.10^{* *}\right)\end{array}$ & $\begin{array}{c}6.06 \\
\left(2.15^{* *}\right)\end{array}$ \\
\hline$o g$ & $\begin{array}{c}-5.37 \\
(3.22 *)\end{array}$ & $\begin{array}{l}-6.37 \\
\left(3.65^{*}\right)\end{array}$ & $\begin{array}{c}-5.14 \\
\left(3.16^{*}\right)\end{array}$ & $\begin{array}{l}-5.50 \\
(3.34 *)\end{array}$ & $\begin{array}{c}-5.33 \\
(3.22 *)\end{array}$ & $\begin{array}{c}-6.28 \\
\left(3.59^{*}\right)\end{array}$ & $\begin{array}{c}-6.51 \\
(3.72 *)\end{array}$ & $\begin{array}{l}-6.26 \\
\left(3.61^{*}\right)\end{array}$ \\
\hline nt & $\begin{array}{l}-0.05 \\
\left(1.68^{\circ}\right)\end{array}$ & $\begin{array}{l}-0.04 \\
(1.26)\end{array}$ & $\begin{array}{l}-0.06 \\
\left(1.80^{\circ}\right)\end{array}$ & $\begin{array}{l}-0.06 \\
\left(1.84^{\circ}\right)\end{array}$ & & $\begin{array}{l}-0.05 \\
(1.41)\end{array}$ & $\begin{array}{l}-0.04 \\
(1.34)\end{array}$ & $\begin{array}{l}-0.05 \\
(1.48)\end{array}$ \\
\hline $\begin{array}{r}\text { Govern } \\
(\mathrm{t}-1, \mathrm{i}\end{array}$ & $\begin{array}{l}-0.02 \\
(0.30)\end{array}$ & $\begin{array}{r}0 \\
(0\end{array}$ & $\begin{array}{c}0 . \\
(0 .\end{array}$ & $\begin{array}{c}0.01 \\
(0.14)\end{array}$ & $\begin{array}{l}0 \\
(0\end{array}$ & $\begin{array}{c}0.01 \\
(0.13)\end{array}$ & $\begin{array}{c}0.01 \\
(0.18)\end{array}$ & $\begin{array}{c}0.01 \\
(0.15)\end{array}$ \\
\hline Index of Glob & $\begin{array}{c}1.02 \\
(2.40 * *)\end{array}$ & $\begin{array}{c}0.92 \\
\left(2.18^{* *}\right)\end{array}$ & $\begin{array}{c}1.12 \\
\left(2.75^{*}\right)\end{array}$ & $\begin{array}{c}0.96 \\
\left(2.39^{* *}\right)\end{array}$ & $\begin{array}{c}0.91 \\
\left(2.19^{* *}\right)\end{array}$ & $\begin{array}{c}1.11 \\
(2.52 * *)\end{array}$ & $\begin{array}{c}1.00 \\
(2.29 * *)\end{array}$ & $\begin{array}{c}1.00 \\
(2.31 * *)\end{array}$ \\
\hline nflation I & $\begin{array}{l}-0.001 \\
\left(4.10^{*}\right)\end{array}$ & $\begin{array}{l}-0.001 \\
(3.97 *)\end{array}$ & $\begin{array}{c}-0.001 \\
(4.60 *)\end{array}$ & $\begin{array}{l}-0.001 \\
\left(4.43^{*}\right)\end{array}$ & $\begin{array}{c}-0.001 \\
\left(3.98^{*}\right)\end{array}$ & $\begin{array}{c}-0.001 \\
(4.07 *)\end{array}$ & $\begin{array}{l}-0.001 \\
(4.01 *)\end{array}$ & $\begin{array}{l}-0.001 \\
(3.90 *)\end{array}$ \\
\hline $\begin{array}{l}\text { Growth Rate of Te } \\
\text { Trade }\end{array}$ & $\begin{array}{c}2.05 \\
\left(1.90^{\circ}\right)\end{array}$ & $\begin{array}{c}3.96 \\
\left(1.84^{\circ}\right) \\
\end{array}$ & $\begin{array}{c}4.34 \\
\left(2.08^{* *}\right) \\
\end{array}$ & $\begin{array}{c}3.64 \\
\left(1.72^{\circ}\right)\end{array}$ & $\begin{array}{c}4.15 \\
(1.96 * *) \\
\end{array}$ & $\begin{array}{c}3.94 \\
\left(1.83^{\circ}\right) \\
\end{array}$ & $\begin{array}{c}3.81 \\
\left(1.76^{\circ}\right) \\
\end{array}$ & $\begin{array}{c}4.06 \\
\left(1.90^{\circ}\right) \\
\end{array}$ \\
\hline Jumber of ob & $\begin{array}{l}345 \\
0.63\end{array}$ & 0.63 & $\begin{array}{l}345 \\
0.64\end{array}$ & $\begin{array}{l}345 \\
0.64\end{array}$ & $\begin{array}{l}345 \\
0.63\end{array}$ & $\begin{array}{l}332 \\
0.63\end{array}$ & $\begin{array}{l}332 \\
0.63\end{array}$ & $\begin{array}{c}332 \\
0.64\end{array}$ \\
\hline
\end{tabular}

Notes:

Compliance is proxied by the share of agreed IMF loans disbursed (3a, 4a), Edwards' variable for program continuation $(3 \mathrm{~b}, 4 \mathrm{~b})$ and, respectively, the measure for equally phased disbursements $(3 \mathrm{c}, 4 \mathrm{c})$.

t-statistics in parentheses.

Levels of significance: 1 percent $(*), 5$ percent $(* *), 10$ percent $\left({ }^{\circ}\right)$.

All regressions include dummies for each time period and country. 
Table 6: Effect of the IMF on Economic Growth (98 countries, 1970-2000, IMF variables instrumented, 3SLS)

\begin{tabular}{|c|c|c|c|c|c|c|c|c|}
\hline & 1 & 2 & $3 a$ & $3 b$ & $3 c$ & $4 a$ & $4 b$ & $4 c$ \\
\hline IMF Program & $\begin{array}{c}-6.30 \\
(2.91 *)\end{array}$ & & & & & $\begin{array}{c}-8.70 \\
(2.42 * *)\end{array}$ & $\begin{array}{c}-7.48 \\
(2.23 * *)\end{array}$ & $\begin{array}{c}-8.40 \\
\left(2.70^{*}\right)\end{array}$ \\
\hline IMF Loans & & $\begin{array}{l}-0.02 \\
(1.58)\end{array}$ & & & & $\begin{array}{l}-0.01 \\
(0.72)\end{array}$ & $\begin{array}{l}-0.01 \\
(0.32)\end{array}$ & $\begin{array}{l}-0.01 \\
(0.61)\end{array}$ \\
\hline Compliance & & & $\begin{array}{c}0.74 \\
(0.13)\end{array}$ & $\begin{array}{c}-6.66 \\
\left(2.57^{* *}\right)\end{array}$ & $\begin{array}{l}-0.32 \\
(0.18)\end{array}$ & & & \\
\hline $\begin{array}{l}\text { IMF Program * } \\
\text { compliance }\end{array}$ & & & & & & $\begin{array}{c}0.11 \\
(1.13)\end{array}$ & $\begin{array}{l}0.06 \\
\left(1.78^{\circ}\right)\end{array}$ & $\begin{array}{c}0.01 \\
(0.45)\end{array}$ \\
\hline $\begin{array}{l}\text { Log (per capita GDP), } \\
\text { beginning of period }\end{array}$ & $\begin{array}{l}-11.98 \\
\left(5.43^{*}\right)\end{array}$ & $\begin{array}{l}-10.60 \\
(3.79 *)\end{array}$ & $\begin{array}{l}-10.90 \\
\left(5.95^{*}\right)\end{array}$ & $\begin{array}{l}-12.84 \\
\left(5.65^{*}\right)\end{array}$ & $\begin{array}{c}-9.42 \\
(5.11 *)\end{array}$ & $\begin{array}{l}-14.45 \\
(3.29 *)\end{array}$ & $\begin{array}{l}-11.80 \\
(3.20 *)\end{array}$ & $\begin{array}{l}-13.12 \\
\left(3.41^{*}\right)\end{array}$ \\
\hline $\begin{array}{l}\text { Secondary School } \\
\text { Enrollment }\end{array}$ & $\begin{array}{l}0.01 \\
(0.23)\end{array}$ & $\begin{array}{l}-0.002 \\
(0.07)\end{array}$ & $\begin{array}{l}-0.02 \\
(0.27)\end{array}$ & $\begin{array}{r}-0.003 \\
(0.11)\end{array}$ & $\begin{array}{l}-0.02 \\
(0.68)\end{array}$ & $\begin{array}{l}-0.02 \\
(0.33)\end{array}$ & $\begin{array}{l}-0.02 \\
(0.50)\end{array}$ & $\begin{array}{l}-0.02 \\
(0.36)\end{array}$ \\
\hline Log (Life Expectancy) & $\begin{array}{c}6.84 \\
(2.11 * *)\end{array}$ & $\begin{array}{l}11.45 \\
\left(1.78^{\circ}\right)\end{array}$ & $\begin{array}{c}5.32 \\
(1.10)\end{array}$ & $\begin{array}{c}2.21 \\
(0.56)\end{array}$ & $\begin{array}{c}6.31 \\
\left(2.27^{* *}\right)\end{array}$ & $\begin{array}{l}20.63 \\
\left(1.91^{\circ}\right)\end{array}$ & $\begin{array}{c}22.82 \\
(2.17 * *)\end{array}$ & $\begin{array}{c}21.33 \\
\left(2.11^{* *}\right)\end{array}$ \\
\hline Log (Fertility Rate) & $\begin{array}{c}-5.25 \\
(2.29 * *)\end{array}$ & $\begin{array}{l}-4.29 \\
\left(1.80^{\circ}\right)\end{array}$ & $\begin{array}{c}-5.16 \\
\left(2.88^{*}\right)\end{array}$ & $\begin{array}{l}-5.77 \\
(2.82 *)\end{array}$ & $\begin{array}{c}-4.14 \\
(2.52 * *)\end{array}$ & $\begin{array}{l}-3.90 \\
(1.20)\end{array}$ & $\begin{array}{l}-3.65 \\
(1.21)\end{array}$ & $\begin{array}{l}-3.13 \\
(1.02)\end{array}$ \\
\hline $\begin{array}{l}\text { Investment ( } \mathrm{t}-1 \text {, } \\
\text { in percent of GDP) }\end{array}$ & $\begin{array}{l}-0.06 \\
(1.55)\end{array}$ & $\begin{array}{l}-0.04 \\
(0.77)\end{array}$ & $\begin{array}{l}-0.05 \\
(1.41)\end{array}$ & $\begin{array}{l}-0.07 \\
\left(1.78^{\circ}\right)\end{array}$ & $\begin{array}{l}-0.03 \\
(0.97)\end{array}$ & $\begin{array}{l}-0.06 \\
(0.82)\end{array}$ & $\begin{array}{l}-0.06 \\
(0.88)\end{array}$ & $\begin{array}{l}-0.06 \\
(0.95)\end{array}$ \\
\hline $\begin{array}{l}\text { Gov. Consumption } \\
\text { (t-1, percent of GDP) }\end{array}$ & $\begin{array}{l}-0.01 \\
(0.10)\end{array}$ & $\begin{array}{l}-0.05 \\
(0.83)\end{array}$ & $\begin{array}{l}0.001 \\
(0.02)\end{array}$ & $\begin{array}{l}-0.03 \\
(0.63)\end{array}$ & $\begin{array}{l}-0.02 \\
(0.31)\end{array}$ & $\begin{array}{l}-0.09 \\
(0.98)\end{array}$ & $\begin{array}{l}-0.06 \\
(0.80)\end{array}$ & $\begin{array}{l}-0.07 \\
(0.84)\end{array}$ \\
\hline Index of Globalization & $\begin{array}{c}1.86 \\
\left(2.71^{*}\right)\end{array}$ & $\begin{array}{c}0.81 \\
(1.41)\end{array}$ & $\begin{array}{c}1.10 \\
(1.18)\end{array}$ & $\begin{array}{c}1.42 \\
\left(2.85^{*}\right)\end{array}$ & $\begin{array}{c}0.64 \\
(1.59)\end{array}$ & $\begin{array}{c}2.93 \\
(1.99 * *)\end{array}$ & $\begin{array}{l}2.50 \\
\left(1.86^{\circ}\right)\end{array}$ & $\begin{array}{c}2.86 \\
(2.18 * *)\end{array}$ \\
\hline $\begin{array}{l}\text { Inflation Rate } \\
\text { (percent) }\end{array}$ & $\begin{array}{l}-0.001 \\
\left(4.03^{*}\right)\end{array}$ & $\begin{array}{l}-0.001 \\
\left(3.19^{*}\right)\end{array}$ & $\begin{array}{l}-0.001 \\
\left(1.85^{\circ}\right)\end{array}$ & $\begin{array}{l}-0.002 \\
(3.02 *)\end{array}$ & $\begin{array}{l}-0.001 \\
\left(3.65^{*}\right)\end{array}$ & $\begin{array}{l}-0.001 \\
(3.00 *)\end{array}$ & $\begin{array}{l}-0.001 \\
\left(3.40^{*}\right)\end{array}$ & $\begin{array}{l}-0.001 \\
\left(3.23^{*}\right)\end{array}$ \\
\hline $\begin{array}{l}\text { Growth Rate of Terms } \\
\text { of Trade }\end{array}$ & $\begin{array}{c}2.19 \\
(0.90) \\
\end{array}$ & $\begin{array}{c}6.80 \\
(2.43 * *) \\
\end{array}$ & $\begin{array}{c}3.17 \\
(1.46)\end{array}$ & $\begin{array}{c}1.88 \\
(0.64) \\
\end{array}$ & $\begin{array}{c}5.39 \\
\left(2.55^{* *}\right) \\
\end{array}$ & $\begin{array}{c}2.48 \\
(0.58) \\
\end{array}$ & $\begin{array}{c}2.43 \\
(0.59) \\
\end{array}$ & $\begin{array}{c}2.92 \\
(0.72) \\
\end{array}$ \\
\hline Numbe & 321 & 229 & 339 & 301 & 328 & 200 & 200 & 200 \\
\hline D & 0.42 & 0.62 & 0.61 & 0.34 & 0.63 & 0.33 & 0.45 & 0.37 \\
\hline
\end{tabular}

Notes:

Compliance is proxied by the share of agreed IMF loans disbursed (3a, 4a), Edwards' variable for program continuation $(3 \mathrm{~b}, 4 \mathrm{~b})$ and, respectively, the measure for equally phased disbursements $(3 \mathrm{c}, 4 \mathrm{c})$. The IMF variables are instrumented with the variables of Table 3 and 4.

t-statistics in parentheses.

Levels of significance: 1 percent $(*), 5$ percent $(* *), 10$ percent $\left({ }^{\circ}\right)$.

All regressions include dummies for each time period and country. 
Appendix A: Definitions and data sources

\begin{tabular}{|c|c|c|}
\hline Variable & Source & Definition \\
\hline IMF programs & $\begin{array}{l}\text { IMF annual report, } \\
\text { various years }\end{array}$ & $\begin{array}{l}\text { Dummy that equals one if an IMF } \\
\text { program has been in effect for at least } 5 \\
\text { months in a specific year. }\end{array}$ \\
\hline IMF loans (percent of GDP) & World Bank (2002) & $\begin{array}{l}\text { IMF purchases are total drawings on the } \\
\text { General Resources Account of the IMF } \\
\text { during the year specified, excluding } \\
\text { drawings in the reserve tranche. }\end{array}$ \\
\hline No program suspension & Edwards (2001a) & $\begin{array}{l}\text { Dummy equals one if a country lost } \\
\text { eligibility for further drawings. }\end{array}$ \\
\hline $\begin{array}{l}\text { Equally phased } \\
\text { disbursements }\end{array}$ & Dreher (2003) & $\begin{array}{l}\text { Percentage of programs where at most } 25 \\
\text { percent of the amount which would be } \\
\text { available for that year under equal } \\
\text { phasing remained undrawn. }\end{array}$ \\
\hline $\begin{array}{l}\text { Share of agreed IMF loans } \\
\text { actually drawn }\end{array}$ & IMF (2003) & $\begin{array}{l}\text { Share of money agreed under an IMF } \\
\text { program and actually drawn until } \\
\text { program expiration. }\end{array}$ \\
\hline growth & World Bank (2003) & $\begin{array}{l}\text { Annual percentage growth rate of GDP } \\
\text { per capita based on constant local } \\
\text { currency. }\end{array}$ \\
\hline $\begin{array}{l}\text { Short-term debt (percent of } \\
\text { total debt) }\end{array}$ & World Bank (2003) & $\begin{array}{l}\text { Short-term debt includes all debt having } \\
\text { an original maturity of one year or less } \\
\text { and interest in arrears on long-term debt. }\end{array}$ \\
\hline $\begin{array}{l}\text { Total debt service (percent of } \\
\text { GDP) }\end{array}$ & World Bank (2003) & $\begin{array}{l}\text { Total debt service is the sum of principal } \\
\text { repayments and interest actually. }\end{array}$ \\
\hline Democracy & $\begin{array}{l}\text { Marshall and } \\
\text { Jaggers }(2000)\end{array}$ & $\begin{array}{l}0-10(0=\text { low; } 10=\text { high }) \text { democracy } \\
\text { score. Measures the general openness of } \\
\text { political institutions. }\end{array}$ \\
\hline LIBOR & IMF (2003) & $\begin{array}{l}\text { London Inter-Bank Offer Rate on 3- } \\
\text { months deposits in the US dollar. }\end{array}$ \\
\hline Political Instability & Dreher (2002) & $\begin{array}{l}\text { Index constructed with principal } \\
\text { components analysis. The weights } \\
\text { obtained for the components are } 0.08 \\
\text { (assassination), } 0.1 \text { (strikes), } 0.25 \\
\text { (guerrilla warfare), } 0.15 \text { (crisis), } 0.16 \\
\text { (riots) and } 0.27 \text { (revolutions). }\end{array}$ \\
\hline Government special interest & Beck et al. (2001) & $\begin{array}{l}\text { Dummy, equals one if at least one } \\
\text { government party is special interest. }\end{array}$ \\
\hline Rule of law & $\begin{array}{l}\text { Gwartney and } \\
\text { Lawson (2002) }\end{array}$ & $\begin{array}{l}\text { Measures the quality of the legal system } \\
\text { and property rights. }\end{array}$ \\
\hline $\begin{array}{l}\text { Foreign direct investment } \\
\text { (percent of GDP) }\end{array}$ & World Bank (2003) & $\begin{array}{l}\text { Foreign direct investment is net inflows } \\
\text { of investment to acquire a lasting } \\
\text { management interest ( } 10 \text { percent or more } \\
\text { of voting stock). }\end{array}$ \\
\hline Freedom of the press & Freedomhouse & $\begin{array}{l}\text { See } \\
\text { http://www.freedomhouse.org/research/ } \\
\text { pressurvey.htm }\end{array}$ \\
\hline Monetary expansion & World Bank (2003) & $\begin{array}{l}\text { Average annual growth rate in money } \\
\text { and quasi money for end-of-year data. }\end{array}$ \\
\hline
\end{tabular}


Appendix A (continued)

\begin{tabular}{|c|c|c|}
\hline Inflation & World Bank (2003) & Consumer price index in percent. \\
\hline Trade (percent of GDP) & World Bank (2003) & $\begin{array}{l}\text { Sum of exports and imports of goods and } \\
\text { services measured as a share of gross } \\
\text { domestic product. }\end{array}$ \\
\hline School enrollment & World Bank (2003) & $\begin{array}{l}\text { Gross enrollment ratio is the ratio of total } \\
\text { enrollment, regardless of age, to the } \\
\text { population of the age group that } \\
\text { officially corresponds to the level of } \\
\text { education shown. Secondary education } \\
\text { completes the provision of basic } \\
\text { education that began at the primary level. }\end{array}$ \\
\hline Civil liberties & $\begin{array}{l}\text { Freedomhouse } \\
(2000)\end{array}$ & $\begin{array}{l}\text { Rates civil liberties with } 1 \text { representing } \\
\text { the most free and } 7 \text { the least free } \\
\text { (http://www.freedomhouse.org/research/ } \\
\text { freeworld/2001/index.htm). }\end{array}$ \\
\hline $\begin{array}{l}\text { Log (per capita GDP), } \\
\text { beginning of period }\end{array}$ & World Bank (2003) & $\begin{array}{l}\text { GDP per capita is gross domestic product } \\
\text { divided by midyear population. Data are } \\
\text { for the end of each five-year period. }\end{array}$ \\
\hline Log (Life Expectancy) & World Bank (2003) & $\begin{array}{l}\text { Life expectancy at birth indicates the } \\
\text { number of years a newborn infant would } \\
\text { live if prevailing patterns of mortality at } \\
\text { the time of its birth were to stay the same } \\
\text { throughout its life. }\end{array}$ \\
\hline Log (Fertility Rate) & World Bank (2003) & $\begin{array}{l}\text { Represents the number of children that } \\
\text { would be born to a woman if she were to } \\
\text { live to the end of her childbearing years } \\
\text { and bear children in accordance with } \\
\text { prevailing age-specific fertility rates. }\end{array}$ \\
\hline Investment (percent of GDP) & World Bank (2003) & Gross domestic investment. \\
\hline $\begin{array}{l}\text { Government Consumption } \\
\text { (percent of GDP) }\end{array}$ & World Bank (2003) & $\begin{array}{l}\text { All government current expenditures for } \\
\text { purchases of goods and services } \\
\text { (including compensation of employees). }\end{array}$ \\
\hline Index of Globalization & Dreher (2002) & $\begin{array}{l}\text { Based on } 23 \text { variables that relate to } \\
\text { different dimensions of globalization. }\end{array}$ \\
\hline
\end{tabular}


Appendix B: Descriptive Statistics

\begin{tabular}{|l|c|c|}
\hline \multicolumn{1}{|c|}{ Variable } & Mean & $\begin{array}{c}\text { Standard Deviation } \\
\text { (overall) }\end{array}$ \\
\hline IMF programs & 0.23 & 0.32 \\
\hline IMF loans (percent of GDP) & 8.40 & 29.40 \\
\hline No program suspension & 0.69 & 0.37 \\
\hline Equally phased disbursements & 0.28 & 0.36 \\
\hline Share of agreed IMF loans actually drawn & 0.74 & 0.38 \\
\hline growth & 1.27 & 3.58 \\
\hline Short-term debt (percent of total debt) & 14.02 & 11.87 \\
\hline Total debt service (percent of GDP) & 5.80 & 4.70 \\
\hline Democracy & 3.38 & 3.72 \\
\hline LIBOR & 7.98 & 2.52 \\
\hline Political Instability & 0.25 & 0.38 \\
\hline Government special interest & 0.15 & 0.34 \\
\hline Rule of law & 4.72 & 1.58 \\
\hline Foreign direct investment (percent of GDP) & 1.13 & 1.56 \\
\hline Freedom of the press & 54.09 & 31.15 \\
\hline Monetary expansion & 57.53 & 250.27 \\
\hline Inflation & 68.57 & 418.72 \\
\hline
\end{tabular}


Appendix C: Countries included in the analysis

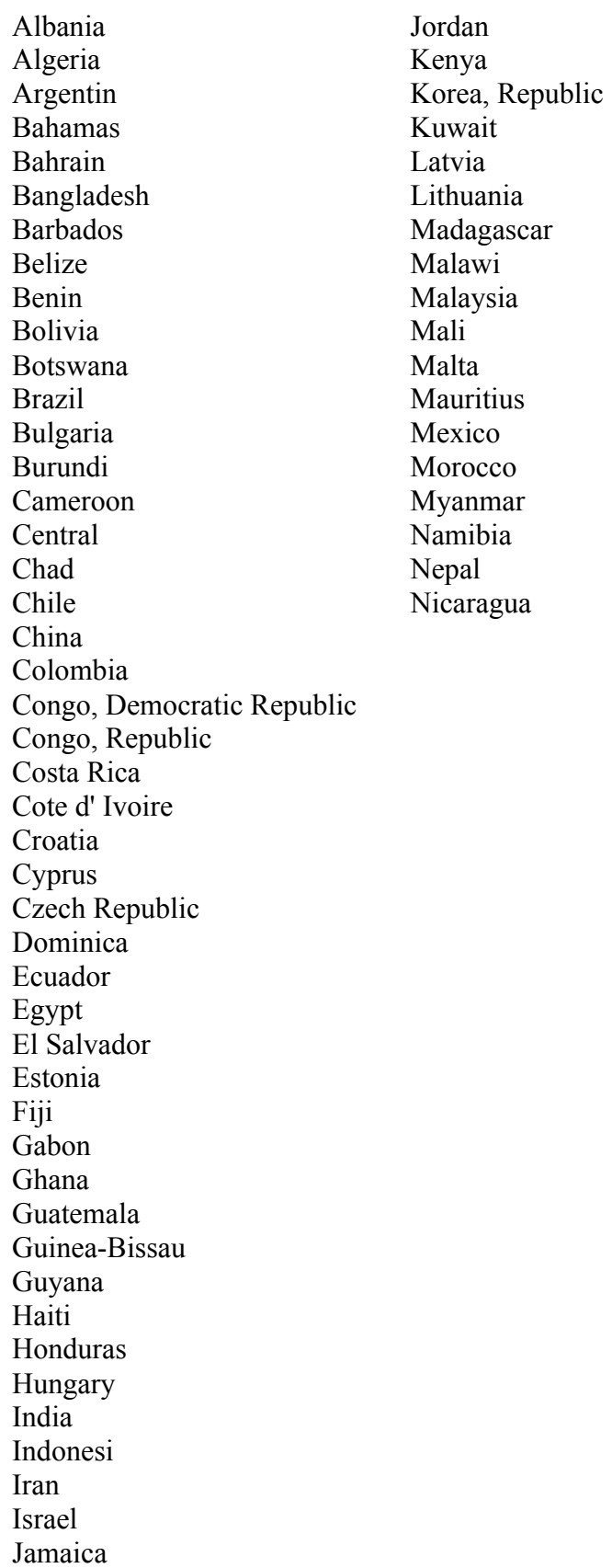




\section{THURGAUER}

WIRTSCHAFTSINSTITUT

an der Universität Konstanz

\section{Hauptstr. 90}

$\mathrm{CH}-8280$ Kreuzlingen 2

Telefon: +41(0)71 6770510

Telefax: +41 (0)71 6770511

info@twi-kreuzlingen.ch

www.twi-kreuzlingen.ch 